\title{
2. EDUCATION FOR CHANGE
}

Ona Ionica Anghel ${ }^{249}$

\begin{abstract}
Specialists in extremely diverse fields draw our attention to a wide range of problems facing humanity, problems that are global, universal, multidisciplinary, with priority: pollution, poverty, depletion of natural resources, war in unseen forms of humanity, pandemic, information explosion, etc. What they all have in common is that their dynamics are accelerated. Even if change is a natural phenomenon, a phenomenon that supports evolution and development, starting with the end of the twentieth century and more and more acute today, there is an acceleration of the rhytm of change in all areas of life. Specialists believe that new content is now needed more than ever to provide the information and skills needed to deal with these problems, content that offers new dimensions of education. This paper aims on the one hand to review the paradigms and theories that could build the trunk of education for change (progressivism and prospectivism), and on the other hand, to list and describe the purposes of an education for change, as pedagogues put us in the theme.
\end{abstract}

Key words: issues of the contemporary world, change, goals, educational strategies

\section{Preliminaries}

The phenomenon of change has been noticed and discussed since ancient times. He was considered vital to evolution. In order to move from one stage of development to another, a change must take place. An education for a changing world would not be so out of the ordinary because the world is naturally constantly changing, but if we think about the speed with which this change is happening, there is an acute need for an education for change, an education that to teach us how to face the challenges imposed by rapid changes (in technologies, in new types of inter-human relationships, in the influx of information, in monetary, etc.)

After the First World War, the acceleration of change is noticed and discussed: a kind of Archimedean „Evrika" discovered in 1918 William Heard Kilpatrick who says „something changes", the world changes much faster. He proposes an education through projects that teach us to relate to an unpredictable future. After the Second World War, the issue of accelerated change is also discussed in Europe, but from a different perspective. Gaston Berger believes that the future can be predicted if we study the present and the past carefully. Depending on this, we can design our attitude models according to the future. Therefore, a new position is drawn towards education and education for change: „something must be changed". The end of the nineteenth century comes with another position on change: man can predict and anticipate as many "possible futures" due to his imagination and experience, and then he can choose from these many possible "futures" the one that satisfies his needs mostly. Denis de Rougemont believes that man should not guess, but decide his future. Therefore, taking this position, we can be much more optimistic about the future because

249 Lecturer PhD., "George Enescu” National University of Arts from Iaşi, Romania, email: ona_anghel@yahoo.com 
"something can be changed" (Antonesei, L. 1996).

Each of these moments (,something is changing”, ,something needs to be changed" and "something can be changed") indicates a change of conception about the phenomenon of "change in society" and about the influence on education, being starting points for education paradigms. change: progressivism: „something changes"; prospectivism: a man for the future: „something must be changed" and a future for man: ,something can be changed".

\section{Paradigms and theories of education for change}

\subsection{Progressive paradigm}

a) the theory of ,child immaturity”, Jhon Dewey

Jhon Dewey's entire pedagogical conception arises from the consideration of the economic, social, and cultural situation in late nineteenth-century America. „Democracy” is a concept that takes on a new nuance after expressing Dewey's opinion, as does the concept of immaturity. Immaturity was previously considered a negative trait of man. Dewey gives it another meaning: that of the precedent of development - where is immaturity, there is also development as a necessity to cover some shortcomings. Dewey's conception of ,immaturity” starts from another notion: „experience”. For him, experience never has a limit because man is always subject to the novelty he must assimilate, he is subject to a permanent adaptation to ever new situations. But if man sets precise goals then he must build actions in accordance with the goals pursued and implicitly adopt appropriate behavior -the action changes the environment.

Knowledge is needed for appropriate, permanently modifiable behavior. The child gains experience against the background of immaturity. According to Dewey, immaturity has two characteristics: dependence and plasticity. Dependence is a trait that helps a child learn from someone else, usually an adult. Plasticity will help him cope when he encounters other situations and apply the means he has acquired through learning to them. If dependence helps him to learn, plasticity helps him to acquire the habit of ,learning to learn”. The ability to learn will not disappear with childhood, but on the contrary. The adult is confronted every day with new situations to which he has to adapt. To a changing world, which offers you something new every day, you must therefore address yourself with adaptability (Callan, E., 1982).

b) the ,project method" theory, William Kilpatrick.

William Heard Kilpatrick is a progressive who has a much stronger conception of change related to education. In fact, he is the first to notice and expose to the general public his findings that „changes are becoming faster after the First World War" (Antonesei, L. 1996, p. 73). He is the first who propose an education for a changing world. His pedagogical conception starts from the situation of the child with his interests in the center of education, which must take into account the increasingly alert pace of change.

Kilpatrick believes that accelerating the pace of change does not allow us to have a very clear picture of the future. We can only know about the future that it could be different from the present, and only the education will prepare us for it. 
Kilpatrick's theory is inspired by Dewey's ideas about change, and his proposed an educational method - the „,project method". Kilpatrick replaces educational objects with solving problems brought to man by daily life. The project „was a general method that could be used all the time, in all subjects, and comprise all forms of behaving and learning, from making a dress, solving a mathematical problem, and writing a letter to memorizing a poem, watching a sunset, and listening to a sonata" (Phillips, D.C., 2014, 667).

Without denying the contribution of progressives to the formation of the idea of education for change, we must also emphasize a limit - that of receiving the future as it is, good or bad, and of adapting to the changes that come with it. This limit will be the starting point for a new paradigm.

\subsection{Prospective paradigm}

Only after the Second World War did Europe begin to feel the accelerated pace of change. The scientific and the technical revolution are spreading and penetrating all corners of social life. The attitude towards change is a little different: something is changing, we have to change ourselves, to change our attitudes and mentality in the first place.

a) building the human required by the future

In the sixth decade Gaston Berger drew attention to the acceleration of social events and the pace of development of human knowledge, but at the same time he believes that the future can be predicted, even projected within certain limits. By studying the present, we can know the future. We study the causes and we can predict the effects. According to Gaston Berger, education must be directed on the one hand to the formation of the capacity to adapt to this changing world, and on the other hand to the formation of the capacity to build the future. This requires „calm, imagination, inventiveness, team spirit, enthusiasm, human sense" (Stanciu, Gh. 1983, p. 209).

Lifelong learning is also very important for the pedagogy of the future. For example, UNESCO responds to global problems through special education programs. A real reform of education on a global scale is happening through them. The problem of accelerated change is thus brought before all mankind, even if it does not appear in the form of education for change, but in the form of lifelong education. Hence the very important role given to the training of trainers. Their quality is vital for the beneficiary, to reach self-education and self-training. Lifelong learning offers man the status of an autonomous person, able to learn continuously, to anticipate and participate in the progress of society.

In Romania, the phenomenon of change is noticed by several specialists. But George Vaideanu is the first who discuss education for change as one of the new sides of education. He best grasps the purpose of education for change, namely, to keep man at the „center of development”. The purpose of education is man himself, his formation so as to meet the requirements of society. Man is the agent and also the beneficiary of the changes: "everything is done through man and for the benefit of man" (Văideanu, G., 1988, p. 117).

Not only the changes in the society attract the attention of the Romanian pedagogue but also those in education. The aims and functions of education, as 
well as its contents or methods are targeted. In the opinion of Văideanu, all these changes have ,evolved from quantitative to qualitative aspects, from specified transformations to elaborated adaptations" (Văideanu, G., 1988, p. 13). The proposed attitude is to build our present according to the future we intend to have: let's get out of the realm of the probable future and build certainties.

b) building the future required by human

Denis de Rougemont looks at the phenomenon of change in an optimistic way. If before the attitude towards change was to adapt to it, the author proposes to anticipate and master future changes. In addition, man can choose for himself what is best for himself and thus from the "multitude of possible futures" to choose the one that suits him best. "Man must not guess, but decide his future" (Antonesei, L., 1996, p. 76). In order for this to be possible, not only the material resources and the changes produced by their reduction or technological evolution must be taken into account, but also the human needs and resources. Considering that human has sufficient (inner) resources, as he has shown over time, he can project his future. It can destroy itself, just as much it can prosper. It is his choice that he alone can make. Therefore, the author argues that education must be conceived in advance for building positive futures.

\section{Aims of education for change}

The purpose of education for change is to „cultivate a complex attitude towards change, in which both the maturity to understand, select and use the best ideas and techniques, as well as the desire to be always open and to accept, in knowledge, contribute. therefore, the fact that they must be replaced" (Jinga, I. 1979, p. 16). Antonesei L. (1998) makes a synthesis of the objectives of education for change:

a) notifying and welcoming the changes - first of all, it is necessary to be aware of the phenomenon of change. Both children and adults need to understand the significance of accelerating changes in our society. There are changes both in the close environment of each - in the type of relationships that do not they are still as stable as before, and this can be scary if we do not know that it is in fact a normal phenomenon - especially in the social, technological, etc. environment. The individual must notice all these changes in order to meet them properly.

b) evaluation of changes and their effects - everyone must also learn that all these changes can occur at a slower or faster pace, they can also be positive or negative changes. Depending on their rhythm and meaning, they must then be able to notice them, to anticipate their effects.

c) designing change and controlling it - anticipating the effects we will be able to evaluate the consequences of the changes, and if it is found that they are bad we will be able to act so as to change their trajectory. That's how we actually learn to choose our future.

\section{Conclusions}

The best way to achieve the goals of education for change is innovative learning (Malita, M., Botkin, J., 1981, Antonesei, L, 1996). Innovative learning 
has two features: anticipation and participation. Stimulating the anticipatory imagination encourages the consideration of trends, the preparation of plans, the evaluation of future consequences and possible side effects.

Anticipation is not limited to predicting or choosing desirable trends and avoiding catastrophic ones. It also creates new alternatives. Participation is more comprehensive, broader; it requires the involvement of all in the phenomenon of change, from ordinary people to those in power. The participation forms he ability to enter into wider relationships, to see the whole of which each individual is a part. In this sense, the most appropriate method for an education for change is problematization.

Being put in front of fictitious problems at the beginning, children will gradually learn to solve real problems, to find the best solutions. Scheduled education and modular education are also very important for achieving the goals of education for change.

Everything is happening with astonishing rapidity and in a short time much of what we know can already be obsolete. That is why it is important to strengthen curiosity, the desire to be constantly aware of everything and that is why we need trained critical thinking, creativity, intellectual and moral autonomy, civic spirit, compassion, but also an increased tolerance for uncertainty. Such competencies require flexibility and openness to changes in education systems.

Even though important steps have been taken in recent years, there are frequent situations in which resistance to change impedes the de facto power of transformation decisions. Resistance is often opposed to innovation, and this comes mainly from people's inflexible conception of reality. That is why it is good to offer models of the processes of change in education, models for solving problems and especially a permanent renewal in order not to happen a stiffening, a hardening on a certain way of life. Although it seems paradoxical, often those who oppose the most resistance to change are precisely those who should promote change - the teachers, the trainers. Therefore, for a change in education to be possible, it is necessary to act on them, on their conceptions and mentality.

\section{References}

1. Antonesei, L. (1996), Paidea, Polirom, Iaşi

2. Berger, G., 1973, Omul modern şi educația sa, [Modern man and his education], Editura Didactică și Pedagogică, București

3. Botkin, J., Elmangjra M., Maliţa M., 1981, Orizontul fără limite ale învăţării, [The limitless horizon of learning], Editura Politică, Bucureşti

4. Callan, E. (1982). Dewey's conception of education as growth. Educational Theory, 32(1), 19-27

5. Phillips D.C., (editor), (2014), Encyclopedia of Educational Theory and Philosophy, Thousend Oaks, CA: Sage, Vol. 2., 665-669

6. Văideanu, G., 1988, Educaţia la frontiera dintre milenii, [Education at the frontier between the millennia], Editura Politică, Bucureşti 